\title{
PERAN KEPUASAN PELANGGAN DALAM MEMEDIASI PENGARUH KUALITAS PELAYANAN TERHADAP LOYALITAS PELANGGAN
}

\author{
I Dewa Agung Gede Adi Utama ${ }^{1}$ \\ Anak Agung Gede Agung Artha Kusuma ${ }^{2}$ \\ ${ }^{1,2}$ Fakultas Ekonomi dan Bisnis Universitas Udayana (Unud), Bali, Indonesia \\ email: gungadi7272@gmail.com
}

\begin{abstract}
ABSTRAK
Kepuasan dan loyalitas adalah dua unsur yang saling melengkapi satu sama lain. Keduanya dibentuk dengan timbulnya suatu nilai yang dipersepsikan oleh konsumen terhadap suatu produk. Penelitian ini bertujuan untuk menguji pengaruh kualitas pelayanan dan kepuasan pelanggan terhadap loyalitas pelanggan bengkel Yamaha Waja Motor Denpasar. Metode penentuan sampel penelitian ini adalah nonprobabilitysampling berbentuk purposive sampling dengan jumlah sampel sebanyak 100 orang responden. Teknik analisis yang digunakan adalah analisis jalur (path analysis) dan uji Sobel. Hasil menunjukkan kualitas pelayanan berpengaruh terhadap kepuasan pelanggan secara positif signifikan, begitupun kualitas pelayanan berpengaruh positif dan signifikan terhadap loyalitas pelanggan, serta kepuasan pelanggan berpengaruh positif signifikan terhadap loyalitas pelanggan. Hasil penelitian juga menunjukan bahwa kepuasan pelanggan mampu memediasi pengaruh kualitas pelayanan terhadap loyalitas pelanggan secara parsial. Berdasarkan hasil itu, maka untuk mewujudkan pelanggan yang loyal manajemen bengkel Yamaha Waja Motor harus terus meningkatkan kualitas pelayanannya, sehingga menciptakan kepuasan dibenak para pelanggan.
\end{abstract}

Kata kunci : kualitas pelayanan, kepuasan pelanggan, loyalitas pelanggan

\section{ABSTRACT}

Satisfaction and loyalty are two elements that complement each other. Both are formed by the emergence of a value perceived by consumers towards a product. This study aims to examine the effect of service quality and customer satisfaction on customer loyalty at Yamaha Waja Motor shop in Denpasar. The method of determining the sample of this research is non probability sampling. The analysis technique used path analysis and Sobel test. The results show that service quality influences customer satisfaction positively significantly, as well service quality has a positive and significant effect on customer loyalty, and customer satisfaction has a significant positive effect on customer loyalty. Customer satisfaction is able to mediate the influence of service quality on customer loyalty partially. Based on these results, to realize loyal customers, Yamaha Waja Motor workshop management must continue to improve the quality of its services, thus creating satisfaction in the minds of customers.

Keywords: service quality, customer satisfaction, customer loyalty 


\section{PENDAHULUAN}

Persaingan bisnis yang semakin kompetitif saat ini menuntut perusahaan penyedia jasa untuk lebih cermat dalam melakukan managemen dan strategi pemasaran. Tujuan utama managemen dan strategi pemasaran yang baik adalah untuk memenangkan persaingan sehingga dapat memperoleh keuntungan yang sebesar-besarnya. Perusahaan yang bergerak di bidang jasa sangat banyak, salah satunya adalah perusahaan penyedia jasa bengkel. Bengkel yang beroperasi ada beberapa jenis, yaitu bengkel umum, bengkel unit keliling, dan bengkel khusus., Selain itu terdapat juga bengkel dealer bermerek khusus seperti bengkel Yamaha, Honda, Suzuki, dan lainnya. Perusahaan penyedia jasa bengkel ini tidak hanya dituntut mampu bersaing satu dengan yang lainnya akan tetapi juga diharapkan mampu memberikan pelayanan terbaik kepada setiap konsumennya.

Kualitas pelayanan yang baik dapat memengaruhi tingkat kepuasan konsumen. Konsumen yang merasa diberikan pelayanan terbaik senantiasa akan tetap berlangganan menggunakan jasa pelayanan tersebut dan pada akhirnya akan dapat menciptakan kesetiaan pelanggan kepada perusahaan. Pelanggan yang sudah merasa puas sangat memungkinkan sekali untuk memberitahukan kepada keluarga dan temannya. Kondisi ini sangat menguntungkan pihak perusahaan dalam meningkatkan jumlah konsumennya. Dengan demikian terciptanya tingkat kepuasan pelanggan yang optimal akan mendorong loyalitas pelanggan terhadap perusahaan. Untuk memenuhi berbagai macam keinginan konsumen, maka sangat diharapkan perusahaan penyedia jasa bengkel mampu memberikan kualitas pelayanan yang bermutu.

Hal ini didukung oleh (Laila dkk., 2012) yang membuktikan bahwa kualitas pelayanan berpengaruh positif dan signifikan terhadap kepuasan pelanggan pengguna jasa sevis bengkel AHASS 0002 di Semarang di bengkel Abidin Lampung Utara. Pelayanan yang bermutu juga sangat bergantung pada kinerja karyawannya, sehingga perlu diberikan pelatihan secara teori maupun praktik langsung di lapangan. juga menyebutkan bahwa pelatihan kerja mempunyai pengaruh yang sangat signifikan terhadap kinerja karyawan bengkel dealer Yamaha Graha Motor Ambulu di Jember.

Yamaha Waja Motor juga merupakan salah satu bengkel dealer Yamaha di Denpasar, selain menjual motor dan spare-part bermerek Yamaha juga memberikan pelayanan jasa servis. Pelayanan servis adalah salah satu sumber pendapatan atau income bagi perusahaan penyedia jasa bengkel selain menjual produk bengkel. Pelayanan servis yang maksimal akan berbanding lurus dengan tingkat kepuasan pelanggan, bahwa kepuasan pelanggan akibat pelayanan dapat menjadi sumber pendapatan bagi perusahaan. Target utama Yamaha Waja Motor dalam memberikan pelayanan jasanya adalah masyarakat pemilik kendaraan bermotor merek Yamaha pada khususnya dan tidak menutup kemungkinan juga memberikan jasa pelayanan bagi jenis kendaraan lainnya. Semakin banyak jumlah target pemasaran jasa dalam hal ini pemilik kendaraan bermotor akan semakin menguntungkan perusahaan. Semakin banyak pemilik kendaraan bermotor akan semakin besar peluang perusahaan meningkatkan keuntungan.Data pusat statistik kota Denpasar menunjukkan bahwa jumlah kendaraan sepeda motor di kota 
Denpasar dari tahun 2012 hingga tahun 2016 cenderung tidak stabil pada setiap tahunnya.

Tabel 1.

Jumlah Sepeda Motor Di Kota Denpasar Tahun 2012-2016

\begin{tabular}{cc}
\hline Tahun & Sepeda Motor \\
\hline 2012 & 618853 \\
2013 & 1377836 \\
2014 & 1038344 \\
2015 & 977774 \\
2016 & 1016328 \\
Total & $\mathbf{5 . 0 2 9 . 1 3 5}$ \\
\hline
\end{tabular}

Sumber: Badan Pusat Statistik Kota Denpasar, 2017

Pada Tabel 1. diatas menunjukkan bahwa jumlah kendaraan sepeda motor hingga tahun 2016 sudah mencapai 5 juta unit dan diduga jumlah ini akan terus meningkat seiring dengan kebutuhan konsumen terhadap sepeda motor. Ada beberapa alasan konsumen lebih butuh motor dibandingkan mobil, yaitu karena lebih cepat sampai (menghemat waktu perjalanan), lebih hemat bahan bakar (lebih ekonomis), harga lebih murah, dan juga karena alasan penampilan yang semakin stylish. Alasan ini diduga menjadi penyebab pertambahan jumlah kendaraan bermotor di kota Denpasar. Pertambahan jumlah kendaraan sepeda motor ini sangat memberikan peluang usaha yang strategis bagi Yamaha Waja Motor untuk memberikan pelayanan jasa servis bagi para konsumen. Yamaha Waja Motor dalam pelaksanaannya memiliki beberapa permasalahan yang sering terjadi pada Yamaha Waja Motor seperti jumlah pelanggan yang datang fluktuatif, menumpuknya jumlah pelanggan yang datang di awal bulan namun pada pertengahan sampai akhir bulan pelanggan yang datang sepidan juga terdapat beberapa pelanggan yang mengeluh dengan kualitas pelayanannya seperti waktu tunggu untuk mendapat pelayanan yang lama sehingga banyak antrian yang terjadi, berdasarkan hal tersebut penelitian ini ingin menganalisis permasalahan yang terjadi pada Yamaha Waja Motor tersebut.

Tujuan penelitian ini adalah untuk menjelaskan pengaruh kualitas pelayanan yang diberikan terhadap kepuasan pelanggan, pengaruh kualitas pelayanan yang diberikan terhadap loyalitas pelanggan, pengaruh kepuasan pelanggan terhadap loyalitas pelanggan serta untuk mengetahui bagaimna peran kepuasan pelanggan dalam memediasi pengaruh kualitas pelayanan terhadap loyalitas pelanggan jasa bengkel Yamaha Waja Motor Denpasar. Hasil penelitian ini diharapkan dapat digunakan sebagai salah satu referensi tambahan dalam bidang ilmu manajemen pemasaran,khususnya dalam aspek kualitas pelayanan.Manfaat praktis terkait penelitian ini diharapkan dapat memberikan suatu masukan untuk beberapa perusahaan dalam penentuan strategi pemasarannya ke depan untuk peningkatan kualitas pelayanan yang kemudian berdampak pada kepuasan pelanggan sehingga diharapkan timbulnya loyalitas daripada pelanggan.

Kerangka konseptual yang diajukan sebagai dasar penentu hipotesis ditunjukan pada Gambar 1. sebagai berikut. 


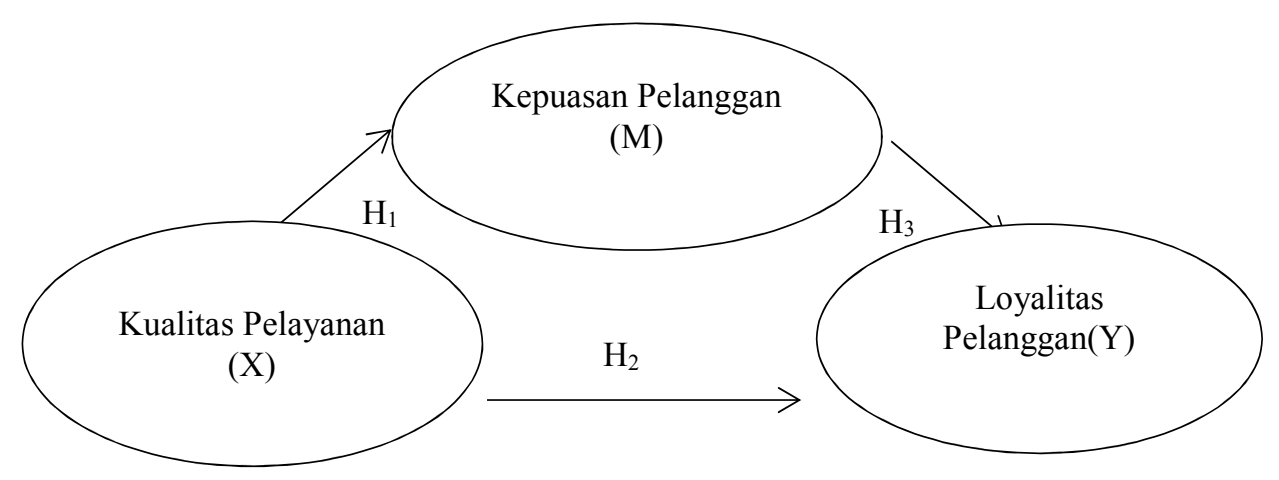

Gambar 1. Kerangka Konseptual Penelitian

Jasa merupakan suatu kinerja penampilan, tidak berwujud dan cepat hilang, lebih dapat berpartisipasi aktif dalam proses mengkonsumsi jasa tersebut. Definisi jasa dalam strategi pemasaran harus diamati secara baik, karena pengertiannya sangat berbeda dengan produk berupa barang. Kualitas jasa merupakan "tingkat" keunggulan yang diharapkan dan pengendalian atas tingkat keunggulan tersebut untuk memenuhi keinginan pelanggan. Kualitas berkaitan erat dengan kepuasan pelanggan. Kualitas memberikan dorongan khusus bagi para pelanggan untuk menjalin ikatan relasi saling menguntungkan dalam jangka panjang dengan perusahaan. Secara umum kualitas pelayanan merupakan faktor penting dalam memperoleh keuntungan yang mengarah pada kesuksesan perusahaan.

Kepuasan pelanggan adalah rasa puas yang dirasakan konsumen setelah menggunakan produk yang sesuai dengan yang diharapkan konsumen (Chahal dan Bala, 2012). Pelanggan merasa puas akan pelayanan barang atau jasa yang mereka dapatkan, besar kemungkinan mereka akan kembali lagi dan melakukan pembelian-pembelian yang lain dan juga akan merekomendasikan pada temanteman dan keluarganya tentangperusahaantersebutdan produk-produknya.

Siddiqi (2014) mengungkapkan bahwa kecil kemungkinannya mereka berpaling ke pesaing-pesaing perusahaan. Kualitas pelayanan dalam suatu perusahaan merupakan faktor yang sangat mempengaruhi kepuasan pelanggan. Mempertahankan kepuasan pelanggan dari waktu ke waktu akan membina hubungan yang baik dengan pelanggan. Hal ini dapat meningkatkan keuntungan perusahaan dalam jangka panjang. Namun demikian, perusahaan harus berhatihati agar tidak terjebak pada keyakinan bahwa pelanggan harus dipuaskan tak peduli berapapun biayanya. Tidak semua pelanggan memiliki nilai yang sama bagi perusahaan. Beberapa pelanggan layak menerima perhatian dan pelayanan yang lebih dibandingkan pelanggan lain. Ada pelanggan yang tidak akan pernah memberikan umpam balik tak peduli berapa banyak perhatian yang kita berikan pada mereka, dan tak peduli berapa puasnya mereka. Dengan demikian, antusiasme tentang kepuasan pelanggan harus didukung oleh analisa-analisa yang tajam. 
Loyalitas muncul didahului oleh kepuasan yang dialami oleh pelanggan. Loyalitas merupakan suatu komitmen akan suatu produk yang bukan hanya tercermin dari perilaku pembelian yang terus menerus. Pembelian berulang atas produk tertentu bisa disebabkan oleh harganya yang murah, dan jikaharganya naik bisa saja pelanggan akan berpaling ke produk lain. Pelanggan yang merasa puas tentu akan menceritakan pengalamannya kepada pelanggan lainnya (word-ofmouthcommunication/komunikasi dari mulut kemulut).Wujud komunikasi dapat berupa penyedia barang ataujasa, rekomendasi kepada calon pelanggan lain,dan berupa dorongan agar melakukan bisnis dengan penyedia barang atau jasa.

Menurut Orel \& Kara (2014) indikator-indikator dari loyalitas pelanggan yakni kesediaan pelanggan untuk berbelanja kembali, kesediaan pelanggan untuk merekomendasikan perusahaan kepada kerabatnya, menjadikan perusahaan sebagai prioritas utama, serta kesediaan pelanggan untuk hanya membicarakan hal positif tentang suatu perusahaan. Loyalitas pelanggan terhadap suatu merek terjadi karena adanya pengaruh kepuasan dan ketidakpuasan dengan merek tersebut yang terakumulasikan secara terus-menerus, di samping adanya persepsi kualitas produk. Dalam membangun loyalitas dimulai dari penciptaan nilai, kepuasan, ketahanan dan loyalitas. Dengan meningkatkan nilai kepada pelanggan dapat meningkatkan tingkat kepuasan dan dapat mengarah pada tingkat ketahanan pelanggan yang lebih tinggi. Ketika pelanggan bertahan karena merasa nyaman dengan nilai dan pelayanan yang mereka dapat, mereka akan lebih mungkin menjadi pelanggan yang loyal. Hal inilah yang menunjukan mahalnya nilai sebuah loyalitas.

Membangunnya tidaklah mudah, karena banyak tantangan yang harus dihadapi serta membutuhkan waktu atau proses yang sangat lama. Akan tetapi sekali loyalitas pelanggan dapat dibangun, akan memberikan manfaat yang besar bagi perusahaan, diantaranya: 1). Mengurangi biaya pemasaran, pelanggan setia dapat mengurangi biaya pemasaran. Beberapa penelitian menunjukan bahwa biaya untuk mendapatkan pelanggan baru enam kali lebih besar dibandingkan dengan biaya untuk mempertahankan pelanggan yang ada. Biaya iklan dan bentuk-bentuk promosi lain dikeluarkan dalam jumlah besar belum tentu dapat menarik pelanggan baru karena tidak gampang membentuk sikap positif terhadap merek; 2). Trade leverage, loyalitas terhadap merek menyediakan trade leverage bagi perusahaan. Sebuah produk atau jasa dengan merek yang memiliki pelanggan setia akan menarik para distributor untuk memberikan ruang yang lebih besar dibandingkan dengan merek lain di perusahaan yang sama. Merek yang memiliki citra kualitas tinggi, akan memaksa konsumen untuk membeli atau merasakan secara berulang-ulang merek yang sama bahkan mengajak konsumen lain untuk membeli merek tersebut; 3). Menarik pelanggan baru, pelanggan yang puas dengan merek yang dibelinya dapat memengaruhi konsumen lain. Pelanggan yang tidak puas akan menyampaikan ketidakpuasannya kepada 8 hingga 10 orang. Sebaliknya bila puas akan menceritakan bahkan merekomendasikan kepada orang lain untuk memilih produk atau jasa yang telah memberikan kepuasan; 4). Merespon ancaman pesaing, loyalitas terhadap pesaing memungkinkan perusahaan memiliki waktu untuk merespons tindakan-tindakan yang dilakukan oleh pesaing. Jika pesaing mengembangkan produk atau jasa yang lebih superior, 
perusahaan memiliki kesempatan untuk membuat produk atau jasa yang lebih baik dalam jangka waktu tertentu karena bagi pesaing relatif sulit untuk mempengaruhi pelanggan-pelanggan yang setia. Mereka butuh waktu yang relatif lama. Karena pentingnya loyalitas pelanggan maka loyalitas pelanggan terhadap merek dianggap sebagai asset perusahaan dan berdampak besar terhadap pangsa pasar serta profitability perusahaan; 5). Nilai kumulatif bisnis berkelanjutan, upaya mempertahankan (retensi) pelaggan dan loyal pada produk perusahaan sepanjang customer lifetime value, dangan cara menyediakan produk yang konstan dibutuhkan secara teratur dengan harga per unit yang lebih rendah.

Loyalitas muncul didahului oleh kepuasan yang dialami oleh pelanggan. Loyalitas merupakan suatu komitmen akan suatu produk yang bukan hanya tercermin dari perilaku pembelian yang terus menerus. Pembelian berulang atas produk tertentu bisa disebabkan oleh harganya yang murah, dan jika harganya naik bisa saja pelanggan akan berpaling ke produk lain. Pelanggan yang merasa puas tentu akan menceritakan pengalamannya kepada pelanggan lainnya (wordof-mouth communication/komunikasi dari mulut ke mulut). Wujud komunikasi dapat berupa penyedia barang atau jasa, rekomendasi kepada calon pelanggan lain,dan berupa dorongan agar melakukan bisnis dengan penyedia barang atau jasa. Indikator dari loyalitas yang kuat adalah: 1. Say positive things, berupa penyampaian kepada orang lain dalam bentuk kata-kata secara positif tentang suatu penyedia jasa, biasanya berupa ulasan cerita atau uraian pengalaman; 2). Recomend friends, adalah proses yang berujung pada mengajak pihak lain untuk ikut menikmati penyedia jasa tersebut akibat dari pengalaman positif yang dirasakan; 3). Continue purchasing, adalah sikap untuk membeli ulang terusmenerus oleh konsumen tersebut pada penyedia jasa tertentu sehingga menimbulkan perulangan yang dapat dilandasi dari kesetiaan.

Menyimpulkan dimensi kualitas jasa sebagai berikut adalah sebagai berikut. 1).Berwujud (tangible), kemampuan perusahaan dalam menunjukkan eksistensinya kepada pihak eksternal. Penampilan dan kemampuan sarana dan prasarana fisik perusahaan yang dapat diandalkan dan keadaan lingkungan sekitar merupakan bukti nyata dari pelayanan yang diberikan oleh pemberi jasa. Hal ini meliputi fasilitas fisik (contoh: gedung-gudang dan lain-lain), perlengkapan dan peralatan yang digunakan (teknologi), serta penampilan pegawai; 2). Keandalan (reliability), kemampuan perusahaan untuk memberikan pelayanan sesuai dengan yang dijanjikan secara akurat dan terpercaya. Kinerja harus sesuai dengan harapan pelanggan yang berarti ketepatan waktu, pelayanan yang sama untuk semua pelanggan tanpa kesalahan,sikap yang simpatik dan dengan akurasi yang tinggi;3). Daya tanggap (responsiviness), suatu kebijakan untuk membantu dan memberikan pelayanan yang cepat dan tepat kepada pelanggan, dengan penyampaian informasi yang jelas. Membiarkan konsumen menunggu tanpa adanya suatu alasan yang jelas menyebabkan persepsi yang negatif dalam kualitas pelayan; 4). Jaminan (assurance), berkaitan dengan pengetahuan, kesopanan dan kemampuan para pegawai perusahaan untuk menumbuhkan rasa percaya para pelanggan kepada perusahaan. Hal ini meliputi beberapa komponen antara lain komunikasi (communication), kredibilitas (credibility), keamanan (security), kompetensi (competence) dan sopan santun (courtesy); 5) Perhatian (empaty), memberikan 
perhatian yang tulus dan bersifat individual atau pribadi yang diberikan kepada pelanggan dengan berupaya memahami keinginan konsumen. Dimana suatu perusahaan diharapkan memiliki pengertian dan pengetahuan tentang pelanggan, memahami kebutuhan pelanggan secara spesifik, serta memiliki waktu pengoperasian yang nyaman bagi pelanggan.

Kualitas pelayanan dalam suatu perusahaan merupakan faktor yang sangat mempengaruhi kepuasan pelanggan. Mempertahankan kepuasan pelanggan dari waktu ke waktu akan membina hubungan yang baik dengan pelanggan. Hal ini dapat meningkatkan keuntungan perusahaan dalam jangka panjang. Namun demikian, perusahaan harus berhati-hati agar tidak terjebak pada keyakinan bahwa pelanggan harus dipuaskan tak peduli berapapun biayanya. Tidak semua pelanggan memiliki nilai yang sama bagi perusahaan. Beberapa pelanggan layak menerima perhatian dan pelayanan yang lebih dibandingkan pelanggan lain. Ada pelanggan yang tidak akan pernah memberikan umpam balik tak peduli berapa banyak perhatian yang kita berikan pada mereka, dan tak peduli berapa puasnya mereka. Dengan demikian, antusiasme tentang kepuasan pelanggan harus didukung oleh analisa-analisa yang tajam.

Teori mengenai pengaruh kualitas pelayanan terhadap kepuasan ini diperkuat oleh beberapa studi empiris yang dilakukan oleh para peneliti sebelumnya, yang dijadikan referensi dalam penelitian ini yaitu Nursiana (2018), dan Mosahab et al. (2014) yang berpendapat sama bahwa kualitas pelayanan berpengaruh positif dan signifikan terhadap kepuasan pelanggan. Selain itu ada juga pendapat yang dikemukakan oleh Canming dan Jianjun (2011) dalam penelitiannya yang menunjukkan bahwa kualitas pelayanan memiliki pengaruh yang besar dan positif terhadap citra perusahaan dan kepuasan pelanggan. Kualitas pelayanan mempunyai pengaruh yang signifikan terhadap kepuasan konsumen. Hasil ini sejalan dengan teori kualitas pelayanan yang dikembangkan oleh Parasuraman et al. (1988). Berdasarkan hasil penelitian empiris tersebut, maka hipotesis yang dapat disimpulkan adalah:

$\mathrm{H}_{1}$ :Kualitas pelayanan berpengaruh positif dan signifikan terhadap kepuasan pelanggan.

Loyalitas muncul didahului oleh kepuasan yang dialami oleh pelanggan. Loyalitas merupakan suatu komitmen akan suatu produk yang bukan hanya tercermin dari perilaku pembelian yang terus menerus. Pembelian berulang atas produk tertentu bisa disebabkan oleh harganya yang murah, dan jika harganya naik bisa saja pelanggan akan berpaling ke produk lain. Pelanggan yang merasa puas tentu akan menceritakan pengalamannya kepada pelanggan lainnya (word-of-mouth communication/komunikasi dari mulut ke mulut). Wujud komunikasi dapat berupa penyedia barang atau jasa, rekomendasi kepada calon pelanggan lain,dan berupa dorongan agar melakukan bisnis dengan penyedia barang atau jasa.

Akan tetapi sekali loyalitas pelanggan dapat dibangun, akan memberikan manfaat yang besar bagi perusahaan, diantaranya:1). Mengurangi biaya pemasaran, pelanggan setia dapat mengurangi biaya pemasaran. Beberapa penelitian menunjukan bahwa biaya untuk mendapatkan pelanggan baru enam kali lebih besar dibandingkan dengan biaya untuk mempertahankan pelanggan yang ada. Biaya iklan dan bentuk-bentuk promosi lain dikeluarkan dalam jumlah besar 
belum tentu dapat menarik pelanggan baru karena tidak gampang membentuk sikap positif terhadap merek; 2). Trade leverage, loyalitas terhadap merek menyediakan trade leverage bagi perusahaan. Sebuah produk atau jasa dengan merek yang memiliki pelanggan setia akan menarik para distributor untuk memberikan ruang yang lebih besar dibandingkan dengan merek lain di perusahaan yang sama. Merek yang memiliki citra kualitas tinggi, akan memaksa konsumen untuk membeli atau merasakan secara berulang-ulang merek yang sama bahkan mengajak konsumen lain untuk membeli merek tersebut; 3). Menarik pelanggan baru, pelanggan yang puas dengan merek yang dibelinya dapat memengaruhi konsumen lain. Pelanggan yang tidak puas akan menyampaikan ketidakpuasannya kepada 8 hingga 10 orang. Sebaliknya bila puas akan menceritakan bahkan merekomendasikan kepada orang lain untuk memilih produk atau jasa yang telah memberikan kepuasan; 4). Merespon ancaman pesaing, loyalitas terhadap pesaing memungkinkan perusahaan memiliki waktu untuk merespons tindakan-tindakan yang dilakukan oleh pesaing. Jika pesaing mengembangkan produk atau jasa yang lebih superior, perusahaan memiliki kesempatan untuk membuat produk atau jasa yang lebih baik dalam jangka waktu tertentu karena bagi pesaing relatif sulit untuk mempengaruhi pelangganpelanggan yang setia. Mereka butuh waktu yang relatif lama. Karena pentingnya loyalitas pelanggan maka loyalitas pelanggan terhadap merek dianggap sebagai asset perusahaan dan berdampak besar terhadap pangsa pasar serta profitability perusahaan; 5). Nilai kumulatif bisnis berkelanjutan, upaya mempertahankan (retensi) pelaggan dan loyal pada produk perusahaan sepanjang customer lifetime value, dangan cara menyediakan produk yang konstan dibutuhkan secara teratur dengan harga per unit yang lebih rendah.

Mosahab et al. (2014) berpendapat bahwa ada pengaruh yang positif antara kualitas pelayanan terhadap loyalitas pelanggan. Hal ini sejalan dengan hasil penelitian yang dilakukan oleh Zarei et al. (2014) yang menyatakan bahwa kualitas pelayanan berpengaruh positif dan signifikan terhadap loyalitas pelanggan. Sementara Muzammil et al. (2017) menemukan bahwa kualitas pelayanan berpengaruh positif dan signifikan terhadap loyalitas pelanggan pada produk IndiHome PT. Telkom Indonesia di Banda Aceh. Berdasarkan hasil penelitian empiris tersebut, maka hipotesis yang dapat disimpulkan adalah:

$\mathrm{H}_{2}$ : Kualitas pelayanan berpengaruh positif dan signifikan terhadap loyalitas pelanggan.

Penelitian Sawitri et al. (2013) memperoleh temuan bahwa kepusan pelanggan berpengaruh positif dan signifikan terhadap loyalitas pelanggan. Setiawan et al. (2016) dalam penelitiannya juga menemukan hasil yang sama, dimana terdapat pengaruh positif dan signifikan dari variabel kepuasan pelanggan terhadap loyalitas pelanggan. Kepuasan produk wisata di wilayah Yogyakarta mempunyai pengaruh yang positif dan signifikan terhadap loyalitas wisatawan yang berkunjung ke Yogyakarta. Berdasarkan hasil penelitian empiris tersebut, maka hipotesis yang dapat disimpulkan adalah:

$\mathrm{H}_{3}$ : Kepuasan pelanggan berpengaruh positif dan signifikan terhadap loyalitas pelanggan. 
Penelitian Aryani dan Rosinta (2010) dalam penelitiannya menujukkan bahwa kepuasan dapat memediasi pengaruh kualitas layanan dengan loyalitas nasabah. Dimana nasabah yang merasa puas akan kualitas layanan yang diberikan oleh perusahaan secara otomatis akan menimbulkan sikap yang loyal. Penelitian yang sama juga dilakukan Malik (2012) dengan hasil bahwa kepuasan pelanggan memiliki pengaruh yang positif dan signifikan dalam memediasi pengaruh kualitas layanan dengan loyalitas pelanggan. Kepuasan pelanggan memiliki peran yang sangat besar dalam memediasi hubungan kualitas layanan dengan loyalitas. Hal ini sesuai dengan penelitian yang dilakukan oleh Thakur dan Singh (2012). Berdasarkan hasil penelitian empiris tersebut, maka hipotesis yang dapat disimpulkan adalah:

H4: Kepuasan pelanggan secara simultan memediasi pengaruh kualitas pelayanan terhadap loyalitas pelanggan.

\section{METODE PENELITIAN}

Penelitian ini menggunakan pendekatan kuantitatif yang berbentuk asosiatif, yaitu suatu penelitian yang meneliti pengaruh suatu variabel terhadap variabel lainnya atau mengetahui hubungan antar variable. Pada penelitian ini untuk mengetahui pengaruh kualitas pelayanan dan kepuasan pelanggan terhadap loyalitas pelanggan pada Yamaha Waja Motor di Kota Denpasar. Data yang diperoleh dalam penelitian ini akan diolah dan dianalisis serta didukung dengan teori pustaka agar dapat membuktikan hipotesis dan menjawab rumusan masalah yang telah dibuat sebelumnya.Penelitian dilakukan di Kota Denpasar, Pertimbangan yang dilakukan untuk memilih Kota Denpasar sebagai lokasi penelitian adalah karena Denpasar menjadi pusat perekonomian di wilayah Bali, sehingga tingkat jumlah kendaraan di wilayah tersebut cukup tinggi. Hal tersebut menyebabkan penduduk Kota Denpasar merupakan pasar potensial bagi Bengkel Yamaha Waja Motor, sehingga menarik peneliti untuk melakukan penelitian di perusahaan tersebut. Obyek dalam penelitian ini adalah kepuasan pelanggan pada kualitas pelayanan yang mengakibatkan timbulnya loyalitas pelanggan.

Variabel bebas dari penelitian ini adalah kualitas layanan (X), variabel mediasi yakni kepuasan pelanggan (M), serta variabel terikat yaitu loyalitas pelanggan (Y). Kualitas pelayanan menurut Fogli dalam Siddiqi (2011) adalah sikap yang berkaitan dengan pelayanan tertentu, kesan keseluruhan pelanggan dari keunggulan organisasi dan pelayanan. Pada penelitian ini menggunakan pendapat menurut Parasuraman et al. (1998) terdapat 5 dimensi kualitas layanan yang telah dimodifikasi dengan tempat penelitian yaitu: 1). Bukti Fisik (Tangibles); 2). Keandalan; 3). Keandalan (Reliability); 4). Daya tanggap (Responsiveness); 5). Jaminan (Assurance).

Kepuasan Pelanggan menurut Andreas (2012) adalah ukuran antara harapan pelanggan akan produk atau jasa dan pengalaman nyata pelanggan dengan produk atau jasa tersebut. Menurut Orel dan Kara (2014) indikator-indikator dari loyalitas pelanggan adalah sebagai berikut: 1). Pelanggan Yamaha Waja Motor Denpasar merasa senang melakukan perbaikan di Yamaha Waja Motor Denpasar; 2). Pelanggan Yamaha Waja Motor Denpasar merasa puas terhadap keseluruhan 
pelayanan yang diberikan; 3). Terpenuhinya harapan pelanggan Yamaha Waja Motor Denpasar setelah menggunakan sparepart dari Yamaha Waja Motor Denpasar.

Loyalitas pelanggan adalah suatu komitmen untuk membeli kembali atau menggunakan kembali pilihan produk atau jasa secara konsisten. Pada penelitian ini, ada 3 indikator yang digunakan dalam menentukan loyalitas pelanggan yaitu: 1). Say positive things, selalu berfikir positif terhadap pelayanan yang diberikan oleh Yamaha Waja Motor Denpasar; 2). Recommend friends, merekomendasikan kepada orang lain untuk menggunakan jasa Yamaha Waja Motor Denpasar; 3). Continue purchasing, selalu menggunakan jasa Yamaha Waja Motor Denpasar dalam melakukan perawatan ataupun perbaikan sepeda motor.

Populasi dalam penelitian ini adalah pelanggan Bengkel Yamaha Waja Motor Denpasar. Jumlah sampel yang representative adalah jumlah indikator dikalikan 5 sehingga jumlah responden yang digunakan dalam penelitian ini adalah 20 indikator dikalikan 5. Maka, responden yang dibutuhkan dalam penelitian ini adalah 100 orang.Pertimbangan yang digunakan dalam memilih responden adalah: 1). Responden dengan pendidikan terakhir SMA/sederajat adalah dengan mempertimbangkan bahwa responden yang minimal berpendidikan SMA/sederajat, sudah dapat memberikan pendapat dan menjawab pertanyaan responden secara rasional; 2). Responden sudah pernah membeli atau menggunakan pelayanan Yamaha Waja Motor Denpasar minimal dua kali.

Metode pengumpulan data dalam penelitian ini dilakukan dengan cara, observasi, interview serta penyebaran instrumen penelitian berupa kuisioner atau angket. Penyebaran kuisoner atau angket dapat dilakukan baik secara langsung oleh peneliti sendiri maupun secara tidak langsung melalui google form serta media lainnya. Kuesioner penelitian terdiri atas pertanyaan maupun pernyataan yang bersifat terbuka yaitu identitas diri responden dan pernyataan yang berkaitan dengan indikator-indikator penelitian.

Jenis data yang digunakan dalam penelitian ini adalah jenis data yang dikelompokkan menurut sifatnya, yaitu data kualitatif dan data kuantitatif. Data kualitatif dalam penelitian ini berupa informasi dari responden mengenai pernyataan ataupun pertanyaan yang tertera di dalam kuisioner maupun informasi dari sumber sekunder. Data kuantitatif dalam penelitian ini berupa laporan serta data statistic dari BPS Kota Denpasar. Sumber data primer dalam penelitian ini berasal dari responden yang memberikan tanggapan atas kuesioner terkait variabel-variabel dalam penelitian. Sumber data sekunder dalam penelitian ini berasal dari lembaga atau institusi yang mempublikasikan data yang dikutip terkait dengan topik penelitian ini, seperti: Yamaha Waja Motor dan media media yang mempublikasikan data terkait penelitian ini.

Penelitian ini menggunakan uji instrumen terlebih dahulu kemudian dilakukan uji sobel. Untuk mengukur validitas dapat dilakukan dengan melakukan korelasi antar skor butir pertanyaan dengan total skor konstruk atau variabel.Sedangkan untuk mengetahui skor masing-masing item pertanyaan valid atau tidak, Pengukuran reliabilitas dapat dilakukan dengan cara yaitu One shot atau pengukuran sekali saja dan kemudian hasilnya dibandingkan dengan pertanyaan yang lain atau mengukur korelasi antara jawaban dengan 
pertanyaan.Uji reliabilitas dapat dilakukan dengan menggunakan bantuan program SPSS, yang akan memberikan fasilitas untuk mengukur reliabilitas dengan uji statistik Cronbach Alpha (a).Suatu konstruk atau variabel dikatakan reliabel jika memberikan nilai Cronbanch Alpha $>0,60$.

Uji sobel dipakai untuk menguji seberapa kekuatan pengaruh tidak langsung antara variabel kualitas pelayanan (X) ke variabel loyalitas pelanggan (Y) melalui variabel kepuasan pelanggan (M). Pengaruh tidak langsung variabel kualitas pelayanan (X) ke variabel loyalitas pelanggan (Y) melalui variabel kepuasan pelanggan (M) dihitung, dengan cara mengalikan antara koefisien jalur (X) terhadap (M) (a), dengan koefisien jalur M terhadap Y (b) atau ab. Standart error dari koefisien a dan $\mathrm{b}$ nantinya ditulis dengan huruf atau symbol $\mathrm{S}$, dan $\mathrm{Sb}$ dan besarnya standart error tidak langsung (indirect effect) S,b. Model path analysis digunakan untuk menganalisis pola hubungan antar variabel dengan tujuan untuk mengetahui pengaruh langsung maupun tidak langsung seperangkat variabel eksogen (kualitas pelayanan) terhadap variabel endogen (loyalitas pelanggan). Dalam analisis ini subjek utamanya adalah variabel-variabel yang memiliki korelasi dan model hubungan antar variabel tersebut ditentukan sebelumnya oleh peneliti. Dasar perhitungan koefisien jalur adalah analisis korelasi dan regresi dalam perhitungan menggunakan software dengan program SPSS 13.00 for windows.

Analisis jalur merupakan teknik model analisis yang digunakan untuk menganalisis pola hubungan antar variabel dengan tujuan untuk mengetahui pengaruh langsung maupun tidak langsung seperangkat variabel bebas terhadap variabel terikat. Masing - masing hipotesis memiliki persamaan struktural yang berbeda sebagai berikut:

$$
\begin{gathered}
\mathrm{Y}_{1}=\beta_{1} X+\mathrm{e} 1 \ldots \ldots \ldots \\
\mathrm{Y}_{2}=\beta_{2} X+\beta_{3} \mathrm{Y}_{1}+\mathrm{e} 2
\end{gathered}
$$

Keterangan:

$\mathrm{Y}=$ loyalitas pelanggan

$\mathrm{X}=$ kualitas pelayanan

$\mathrm{M}=$ kepuasan pelanggan

$\mathrm{P}=$ koefisien garis regresi

\section{HASIL DAN PEMBAHASAN}

Yamaha Waja Motor merupakan salah satu bagian keluarga besar Yamaha yang ada di Bali yang didirikan oleh Bapak Tjandanarsa yang sampai saat ini sangat akrab dengan sebutan Pak Lengar. Awal mulanya dimulai dengan membuka bengkel umum di tahun 1974, kemudian setelah beberapa tahun berikutnya dipercaya untuk membuka dealer Vespa di area Bali Timur. Lima tahun berikutnya Pak Lengar beralih ke Yamaha dan mulai membuka dealer resmi Yamaha di tahun 1984. Toko pertama Yamaha Waja Motor berlokasi di jalan Udayana no 1 Blahbatuh Gianyar.

Tahun-tahun berikutnya, dengan semangat dan etos kerja yang maksimal, Pak Lengar mampu mendirikan lagi beberapa cabang Waja Motor yang melayani Penjualan, Service dan Spare Part (3S). Diantaranya Waja Sentral 1994 , Waja Ubud 1996 , Waja Sukawati 1998, Waja Bangli 2000 , Waja Hayam Wuruk 2002 
, Waja Klungkung 2005, Waja Ahmad Yani 2006 dan yang terbaru di tahun 2012 adalah Waja Motor Tabanan. Selain ke 8 dealer resmi Yamaha yang lengkap melayani penjualan service dan spare part, Waja Motor juga memiliki beberapa sub dealer 2S (melayani Service dan Spare Part), chanel ini didirikan untuk mengcover konsumen dalam pelayanan after sales dan lebih mendekatkan Waja di hati konsumen.

Berdasarkan kriteria usia yang ditentukan, responden dengan rentang usia 26 sampai 35 tahun mendominasi sebaran kuesioner ini, yaitu sebesar 47\%. Hal tersebut menunjukan bahwa mayoritas responden berada pada rentang usia dewasa. Sisanya responden dengan rentang usia 18 sampai 25 tahun sebesar $20 \%$ serta responden dan rentang usia 36 tahun keatas sebesar 33\%.

Berdasarkan hasil data pada Tabel 4.1dapat digambarkan bahwa responden dalam penelitian ini didominasi oleh pria yaitu sebanyak $78 \%$, sementara sisanya yaitu sebanyak $22 \%$ berjenis kelamin wanita. Hasil sebaran ini dapat berarti bahwa lebih banyak konsumen pria yang menggunakan jasa Bengkel Yamaha Waja Motor dibanding dengan konsumen wanita saat penyebaran kuesioner dilakukan.

Berdasarkan klasifikasi pekerjaannya, jumlah responden dengan klasifikasi pekerjaan swasta mendominasi sebaran kuesioner dengan persentase sebesar $46 \%$. Sisanya responden yang berstatus pelajar atau mahasiswa yaitu sebesar 19\%, PNS sebesar $22 \%$ serta yang lainnya sebesar $13 \%$. Hal ini menunjukan bahwa animo masyarakat di kalangan pekerja swasta untuk menggunakan jasa Bengkel Yamaha Waja Motor sangatlah tinggi.

Rata-rata persepsi responden mengenai variabel kualitas pelayanan secara keseluruhan adalah sebesar 4,17 sehingga masuk dalam kriteria cukup tinggi. Artinya responden mempunyai persepsi bahwa jasa Bengkel Yamaha Waja Motor mampu memberikan value bagi para penggunanya. Berdasarkan hasil deskripsi persepsi responden terhadap variabel kualitas pelayanan yang diukur dengan 14 indikator menunjukkan nilai rata-rata tertingi pada pernyataan nomor 2 yaitu pernyataan "Fasilitas fisik Yamaha Waja Motor Denpasar lengkap" dengan nilai sebesar 4,29. Hal ini mengindikasikan bahwa pelanggan cenderung merasa ketersediaan berbagai sarana dan prasarana fisik perusahaan telah sesuai dengan apa yang diharapkan.

Rata-rata persepsi responden mengenai variabel kepuasan pelanggan secara keseluruhan adalah sebesar 4,11 sehingga masuk dalam kriteria cukup tinggi. Artinya responden mempunyai persepsi bahwa jasa Bengkel Yamaha Waja Motor mampu memberikan kepuasan bagi para konsumen. Berdasarkan hasil deskripsi persepsi responden terhadap variabel kepuasan pelanggan yang diukur dengan 3 indikator menunjukkan nilai rata-rata tertingi pada pernyataan nomor 2 yaitu pernyataan "Pelanggan Yamaha Waja Motor Denpasar merasa puas terhadap keseluruhan pelayanan yang diberikan" dengan nilai sebesar 4,45. Hal ini mengindikasikan bahwa pelanggan cenderung merasa puas terhadap seluruh pelayanan yang Bengkel.

Rata-rata persepsi responden mengenai variabel loyalitas pelanggan secara keseluruhan adalah sebesar 4,16 sehingga masuk dalam kriteria cukup tinggi. Artinya responden mempunyai persepsi bahwa pelayanan yang diberikan jasa 
Bengkel Yamaha Waja Motor mampu membuat para penggunanya untuk tetap loyal. Berdasarkan hasil deskripsi persepsi responden terhadap variabel loyalitas pelanggan yang diukur dengan 3 indikator menunjukkan nilai rata-rata tertingi pada pernyataan nomor 2 yaitu pernyataan "Merekomendasikan kepada orang lain untuk menggunakan jasa Yamaha Waja Motor Denpasar" dengan nilai sebesar 4,22. Hal ini mengindikasikan bahwa pelanggan cenderung berniat untuk mengajak pihak lain untuk ikut menikmati pelayanan yang diberikan jasa Bengkel Yamaha Waja Motor tersebut akibat dari pengalaman positif yang dirasakan.

Pertama dilakukan uji instrument terlebih dahulu untuk menentukan apakah instrument dapat digunakan dalam penelitian ini. Suatu instrumen dikatakan valid apabila Pearson Correlation terhadap skor total di atas 0,30 . Hasil uji validitas instrumen penelitian disajikan pada Tabel berikut yang menunjukkan bahwa seluruh indikator pertanyaan dalam variabel kualitas layanan, kepuasan pelanggan, dan loyalitas pelanggan memiliki nilai Pearson Correlation yang lebih besar dari angka 0,30 sehingga seluruh indikator tersebut telah memenuhi syarat validitas data. Hasil pengukuran validitas masing-masing instrumen pada variabel disajikan dalam Tabel 2. sebagai berikut.

Tabel 2.

Hasil Uji Validitas

\begin{tabular}{cccc}
\hline Variabel & Instrumen & $\begin{array}{c}\text { Pearson } \\
\text { Correlation }\end{array}$ & Keterangan \\
& X.1 & 0,722 & Valid \\
& X.2 & 0,726 & Valid \\
& X.3 & 0,673 & Valid \\
& X.4 & 0,598 & Valid \\
Kualitas Layanan & X.5 & 0,649 & Valid \\
(X) & X.6 & 0,684 & Valid \\
& X.7 & 0,712 & Valid \\
& X.8 & 0,630 & Valid \\
& X.9 & 0,681 & Valid \\
& X.10 & 0,743 & Valid \\
Kepuasan Pelanggan & X.11 & 0,692 & Valid \\
(M) & X.12 & 0,715 & Valid \\
& X.13 & 0,726 & Valid \\
& X.14 & 0,651 & Valid \\
Loyalitas Pelanggan & M.1 & 0,730 & Valid \\
(Y) & M.3 & 0,766 & Valid \\
& Y.1 & 0,840 & Valid \\
& Y.2 & 0,906 & Valid \\
& Y.3 & 0,832 & Valid \\
\hline
\end{tabular}

Sumber:Data diolah, 2018

Hasil uji validitas instrumen penelitian disajikan pada Tabel 2. yang menunjukkan bahwa seluruh indikator dalam variabelmemiliki nilai Pearson Correlation yang lebih besar dari angka 0,30 sehingga seluruh indikator tersebut dikatakan telah memenuhi syarat validitas data. 
Uji reliabilitas bertujuan untuk mengetahui sejauh mana alat ukur dapat dipercaya atau dapat diandalkan. Pengujian reliabilitas dilakukan terhadap instrumen dengan koefisien cronbach's alpha. Apabila nilai cronbach's alpha lebih besar dari 0,60 maka instrumen yang digunakan reliabel. Hasil uji reliabilitas instrumen pada penelitian ini disajikan pada Tabel 3. berikut yang menunjukkan bahwa ketiga instrumen penelitian yaitu kualitas layanan, kepuasan pelanggan, dan loyalitas pelanggan memiliki koefisien cronbach's alpha yang lebih besar dari angka 0,60 sehingga pernyataan pada kuesioner tersebut dapat dikatakan reliabel.

Tabel 3.

Hasil Uji Reliabilitas

\begin{tabular}{ccc}
\hline Variabel & Cronbach's Alpha & Keterangan \\
\hline Kualitas Layanan (X) & 0,913 & Reliabel \\
Kepuasan Pelanggan (M) & 0,677 & Reliabel \\
Loyalitas Pelanggan (Y2) & 0,840 & Reliabel \\
\hline
\end{tabular}

Sumber: Data diolah, 2018

Hasil uji reliabilitas instrumen pada penelitian ini disajikan pada Tabel 3. yang menunjukkan bahwainstrumen penelitian memiliki koefisien cronbach's alpha yang lebih besar dari angka 0,60 sehingga pernyataan pada kuesioner dapat dikatakan reliabel dan indikator yang digunakan merupakan indikator yang konsisten.

Penelitian ini menggunakan Analisis Jalur (Path Analysis) sebagai metode penelitiannya. Metode ini merupakan perluasan dari metode regresi linear berganda untuk menguji hubungan kausalitas antar dua variabel atau lebih. Berikut penjelasan lebih rinci mengenai tahapan dalam pengujian analisis jalur.

Tabel 4.

Hasil Analisis Jalur Persamaan Regresi 1

\begin{tabular}{cccc}
\hline \multirow{2}{*}{ Model } & \multirow{2}{*}{ RSquare } & Standardized Coefficients & \multirow{2}{*}{ Sig. } \\
\cline { 3 - 3 } & & Beta & 0,000 \\
\hline Kualitas Layanan & 0,410 & 0,541 & \\
\hline
\end{tabular}

Sumber: Data diolah, 2018

Berdasarkan hasil analisis jalur substruktural 1 yang disajikan pada Tabel 4, maka persamaan strukturalnya adalah:

$$
\mathrm{M}=0,541 \mathrm{X}+\mathrm{e}_{1}
$$

Tabel 5.

Hasil Analisis Jalur Persamaan Regresi 2

\begin{tabular}{lccc}
\hline \multicolumn{1}{c}{ Model } & R Square & $\begin{array}{c}\text { Standardized } \\
\text { Coefficients } \\
\text { Beta }\end{array}$ & Sig. \\
\hline Kualitas Layanan & 0,617 & 0,634 & 0,000 \\
Kepuasan Pelanggan & & 0,235 & 0,002 \\
\hline Sumber: Data diolah, 2018 & &
\end{tabular}


Berdasarkan hasil analisis jalur substruktural 2 yang disajikan pada Tabel 5, maka persamaan strukturalnya adalah:

$\mathrm{Y}=0,634 \mathrm{X}+0,235 \mathrm{M}+\mathrm{e}_{2}$

Berdasarkan hasil analisis pengaruh kualitas layanan terhadap kepuasan pelanggan, diperoleh hasil nilai koefisien beta 0,541 dengan nilai signifikansi sebesar 0,000. Nilai koefisien beta $>0$ dan nilai signifikansi $<0,05$ mengindikasikan bahwa kualitas layanan berpengaruh positif dan signifikan terhadap kepuasan pelanggan. Dengan demikian, $\mathrm{H}_{1}$ diterima.

Berdasarkan hasil analisis pengaruh kualitas layanan terhadap loyalitas pelanggan, diperoleh hasil nilai koefisien beta 0,634 dengan nilai signifikansi sebesar 0,000. Nilai koefisien beta $>0$ dan nilai signifikansi $<0,05$ mengindikasikan bahwa kualitas layanan berpengaruh positif dan signifikan terhadap loyalitas pelanggan. Dengan demikian, $\mathrm{H}_{2}$ diterima.

Berdasarkan hasil analisis pengaruh kepuasan pelanggan terhadap loyalitas pelanggan, diperoleh hasil nilai koefisien beta 0,235 dengan nilai signifikansi sebesar 0,002. Nilai koefisien beta $>0$ dan nilai signifikansi $<0,05$ mengindikasikan bahwa kepuasan pelanggan berpengaruh positif dan signifikan terhadap loyalitas pelanggan. Dengan demikian, $\mathrm{H}_{3}$ diterima.

Nilai determinasi total sebesar 0,487 mempunyai arti bahwa sebesar $48,7 \%$ variasi loyalitas pelanggan dipengaruhi oleh variasi kualitas layanan dan kepuasan pelanggan, sedangkan sisanya sebesar $51,3 \%$ dijelaskan oleh faktor-faktor lain yang tidak dimasukkan ke dalam model.

\section{Tabel 6.}

Pengaruh Langsung dan Pengaruh Tidak Langsung serta Pengaruh Total

\begin{tabular}{cccc}
\hline $\begin{array}{l}\text { Pengaruh } \\
\text { Variabel }\end{array}$ & $\begin{array}{l}\text { Pengaruh } \\
\text { Langsung }\end{array}$ & $\begin{array}{l}\text { Pengaruh Tidak Langsung } \\
\text { Melalui Mediasi } \\
\left(\boldsymbol{\beta}_{\mathbf{1}} \mathbf{x} \boldsymbol{\beta}_{3}\right)\end{array}$ & Pengaruh Total \\
\hline $\mathrm{X} \rightarrow \mathrm{M}$ & 0,541 & - & 0,541 \\
$\mathrm{X} \rightarrow \mathrm{Y}$ & 0,634 & $(0,541 \times 0,235)=0,127$ & 0,761 \\
$\mathrm{M} \rightarrow \mathrm{Y}$ & 0,235 & - & 0,235 \\
\hline
\end{tabular}

Sumber: Data diolah, 2018

Berdasarkan Tabel 6. dapat disimpulkan bahwa kualitas layanan memiliki pengaruh langsung terhadap loyalitas pelanggan dan pengaruh tidak langsung melalui kepuasan pelanggan. Hasil koefisien pengaruh tidak langsung lebih kecil dibandingkan pengaruh langsung $(0,634<0,127)$, sehingga dapat dikatakan bahwa variabel kepuasan pelanggan adalah sebagai variabel mediasi dalam memediasi pengaruh variabel kualitas layanan tehadap variabel loyalitas pelanggan.

Jika nilai $\mathrm{Z}$ hitung lebih besar dari $\mathrm{Z}$ tabel, maka dapat disimpulkan terjadi pengaruh mediasi. Berdasarkan perhitungan, didapatkan nilai $\mathrm{Z}$ hitung sebesar 8,4086 yang artinya lebih besar dari $Z$ tabel yaitu $1,9847(8,4086>1,9847)$. Dapat disimpulkan bahwa kepuasan pelanggan mampu memediasi pengaruh kualitas layanan terhadap loyalitas pelanggan.

Hasil pengujian menunjukan hasil bahwa nilai koefisien beta positif sebesar 0,541 dengan tingkat signifikansi sebesar 0,000 (kurang dari 0,05) yang artinya $\mathrm{H}_{1}$ 
diterima. Hasil ini mengindikasikan bahwa variabel perceived value berpengaruh positif serta signifikan terhadap kepuasan pelanggan. Hasil pengujian menunjukan bahwa semakin baik kualitas pelayanan jasa bengkel Yamaha Waja Motor Denpasar, maka semakin meningkat pula kepuasan para pelanggan. Begitupun sebaliknya jika kualitas pelayanan jasa bengkel Yamaha Waja Motor Denpasar semakin buruk, maka semakin rendah pula kepuasan para pelanggan.

Hasil pengujian selanjutnya menunjukan hasil bahwa nilai koefisien beta positif sebesar 0,446 dengan tingkat signifikansi sebesar 0,000 (kurang dari 0,05) yang artinya $\mathrm{H}_{2}$ diterima. Hasil pengujian menunjukan bahwa semakin baik kualitas pelayanan jasa bengkel Yamaha Waja Motor Denpasar, maka semakin semakin tinggi pula loyalitas para pelanggan. Begitupun sebaliknya jika kualitas pelayanan jasa bengkel Yamaha Waja Motor Denpasar semakin buruk, maka semakin rendah pula loyalitas para pelanggan.

Hasil pengujian menunjukan hasil bahwa nilai koefisien beta positif sebesar 0,235 dengan tingkat signifikansi sebesar 0,002 (kurang dari 0,05) yang artinya H3 diterima. Hasil pengujian menunjukan bahwa semakin tinggi kepuasan pelanggan jasa bengkel Yamaha Waja Motor Denpasar, maka semakin tinggi pula loyalitas para pelanggan. Begitupun sebaliknya jika kepuasan pelanggan jasa bengkel Yamaha Waja Motor Denpasar semakin rendah maka semakin rendah pula loyalitas para pelanggan.

Hasil pengujian yang terakhir menunjukkan pengaruh tidak langsung kualitas pelayanan terhadap loyalitas pelanggan melalui kepuasan pelanggan menghasilkan nilai $\mathrm{Z}$ hitung sebesar 8,4086 yang lebih besar dibanding dengan $\mathrm{Z}$ tabel yaitu 1,98 , sehingga $\mathrm{H}_{4}$ diterima. Hasil ini dapat menjelaskan bahwa loyalitas pelanggan jasa bengkel Yamaha Waja Motor Denpasar akan baik, tidak hanya dengan kualitas pelayanan yang baik saja, namun diikuti dengan kepuasan pelanggan yang baik pula.

Implikasi dari hasil penelitian ini adalah membuktikan bahwa kualitas layanansecara positif dan signifikan mempengaruhi kepuasanpelanggan, dalam hal ini berkaitan proses layanan dari mekanik bengkel dan juga peralatan yang terdapat di dalam bengkel yang sesuai dengan kebutuhan. Oleh sebab itu bengkel Yamaha Waja Motor sebaiknya mulai memperbaiki sistem antrian disitu dengan melakukan sistem registrasi online maupun penambahan jumlah mekanik. Kemudian membuktikan pula bahwa kepuasan pelanggan secara simultan memediasi pengaruh kualitas pelayanan terhadap loyalitas pelanggan. Hal ini menunjukkan bahwa bengkel Yamaha Waja Motor sangat berpeluang menciptakan loyalitas dibenak para konsumennyadengan memberikan pendekatan dari segi layanan yang baik kepada pelanggan berkaitan denganapa yang dibutuhkan, sehingga para pelanggan merasa terpenuhi harapannya. Kepuasan terhadap kinerja bengkel Yamaha Waja Motorakan mebentuk loyalitas dari pelanggan yang menggunakan jasa bengkel Yamaha Waja Motor.

Namun terdapat beberapa keterbatasan yakni penelitian ini hanya dilakukan pada titik waktu tertentu (cross section) yang bersifat periodik dimana lingkungan yang bersifat dinamis sehingga terus mengalami perubahan.Penelitian hanya dilakukan pada salah satu cabang bengkel Yamaha Waja Motor, sehingga hasil penelitian tidak sepenuhnya menggambarkan kondisi realita yang terjadi. Serta 
kurangnya pemahaman dari beberapa responden terhadap pernyataan-pernyataan serta sikap kepedulian dan keseriusan dalam menjawab kuesioner.

\section{SIMPULAN}

Berdasarkan hasil pembahasan, dapat ditarik beberapa simpulan sebagai berikut: 1). Kualitas pelayanan berpengaruh positif signifikan terhadap kepuasan pelanggan. Hasil penelitian ini menunjukkan bahwa semakin tinggi kualitas pelayanan pelanggan bengkel Yamaha Waja Motor, maka semakin tinggi pula kepuasan para pelanggan. Begitupun sebaliknya jika semakin rendah kualitas pelayanan pelanggan bengkel Yamaha Waja Motor, maka semakin rendah pula kepuasan para pelanggan; 2). Kualitas pelayanan berpengaruh positif signifikan terhadap loyalitas pelanggan. Hasil penelitian ini menunjukkan bahwa semakin tinggi kualitas pelayanan pelanggan bengkel Yamaha Waja Motor, maka semakin tinggi pula loyalitas para pelanggan. Begitupun sebaliknya jika semakin rendah kualitas pelayanan pelanggan bengkel Yamaha Waja Motor, maka semakin rendah pula loyalitas para pelanggan; 3). Kepuasan pelanggan berpengaruh positif signifikan terhadap loyalitas pelanggan. Hasil penelitian ini menunjukkan bahwa semakin tinggi kepuasan pelanggan bengkel Yamaha Waja Motor, maka semakin tinggi pula loyalitas para pelanggan. Begitupun sebaliknya jika semakin rendah kepuasan pelanggan bengkel Yamaha Waja Motor, maka semakin rendah pula loyalitas para pelanggan; 4). Kepuasan pelanggan berpengaruh signifikan dalam memediasi pengaruh variabel kualitas pelayanan terhadap variabel loyalitas pelanggan.

Hasil ini menunjukan bahwa kualitas pelayanan yang dirasakan pelanggan bengkel Yamaha Waja Motor sesuai dengan kepuasan yang diperoleh pelanggan saat menggunakan jasa bengkel Yamaha Waja Motor, sehingga timbul loyalitas yang tinggi. Efek mediasi yang terjadi adalah mediasi parsial atau partial mediation karena pada penelitian ini pengaruh kualitas pelayanan terhadap loyalitas pelanggan secara langsung mendapatkan hasil yang signifikan, begitupun dengan pengaruhnya secara tidak langsung melalui variabel mediasi yaitu kepuasan pelanggan.

Berdasarkan hasil analisis dari simpulan, maka saran yang dapat diberikan kepada pihak-pihak yang membutuhkan hasil kajian ini adalah bagi perusahaan, selama proses pelayanan terdapat beberapa indikator penilaian yang harus diperhatikan dan dalam penilaian tersebut didapatan bahwa indikator keramahan pegawai memiliki nilai yang paling rendah dibandingkan indikator lainya jadi melihat hal tersebut diharapkan bagi perusahaan untuk lebih menjaga perilaku karyawan terhadap pelanggan sehinggan konsumen merasa lebih nyaman. Selanjutnya, kurangnya perhatian perhatian khusus menjadi indikator dengan nilai rata-rata terkecil pada variabel kepuasan pelanggan. Hal ini mengindikasikan bahwa pelanggan membutuhkan suatu nilai tambah. Perusahaan dituntut untuk dapat memberikan nilai tambah dari pelayanan yang mereka berikan, dengan melakukan inovasi ini maka tingkat kepuasan akan meningkat.

Bagi peneliti selanjutnya, apabila ingin melakukan penelitian serupa diharapkan untuk melakukan penelitian dengan cakupan yang lebih luas, menambah variabel-variabel lain diluar penelitian ini serta diharapkan mampu 
menambah indikator-indikator terhadap variabel yang akan diteliti.Penelitian berikutnya diharapkan lebih jeli dalam memilih sampel penelitian, sehingga tingkat keakurasian hasil data lebih akurat. Selain itu juga diharapkan lebih objektif dalam interpretasi hasil analisis data, sehingga semakin ilmiah investigasi penelitian.

\section{REFERENSI}

Aryani, Rosinta. 2010. Pengaruh Kualitas Layanan Terhadap Kepuasan Pelanggan Dalam Membentuk Loyalitas Pelanggan DWI, 18(1), 66-73.

Andreas, Julius. 2012. Pengaruh Brand Credibility terhadap Word of mouth Melalui Customer Satisfaction dan Customer loyalty Pada Giant Hypermarket di Surabaya. Jurnal universitas katolik widya mandala Surabaya, 11 (4) : 1-8.

Briliana, Vita. 2013. Pengaruh Kepuasan, Komitmen, Manfaat Sosial, dan Special Treatment BenefitsTerhadap Loyalitas Pelanggan.Jurnal Bisnis dan Akuntansi 1.15(1): 57-64.

Canming, C. A. O., Jianjun, C. 2011. An Empirical Analysis of tiie Reiatlonship Among the Service Quaiity, Customer Satisfaction and Loyaity of Higii Speed Railway Based on Strctural Equation Modei Résumé. 7(4), 67-73.

Chahal, H., Bala, M. 2012. Significant components of service brand equity in healthcare sector. International Journal of Health Care Quality Assurance, $25(4), 343-362$.

Chu, Po-Young; Lee, Gin-Yuan; Chao, Yu. 2012. Service Quality, Customer Satisfaction, Customer Trust, And Loyalty In An E Banking, SocialBehavior and Personality, 40(8):1271-1283

Demirci Orel, F., Kara, A. 2014. Supermarket self-checkout service quality, customer satisfaction, and loyalty: Empirical evidence from an emerging market. Journal of Retailing and Consumer Services, 21, 2013-2015.

Malik, S. U. 2012. Customer Satisfaction, Perceived Service Quality and Mediating Role of Perceived Value. International Journal of Marketing Studies, 4(1).

Mosahab, R., Mahamad, O., Ramayah, T. 2014. Service Quality, Customer Satisfaction and Loyalty: a Test of Mediation. International Business Research, 3(4), 72-80.

Muzammil, A., Yunus, M., \& Darsono, N. 2017. Pengaruh Kualitas Pelayanan Dan Citra Perusahaan Terhadap Loyalitas Pelanggan Indihome Pt. Telkom 
I Dewa Agung Gede, Adi Utama. Peran Kepuasan Pelanggan...

Indonesia Di Banda Aceh Dengan Kepuasan Dan Kepercayaan Pelanggan Sebagai Variabel Mediasi. Jurnal Manajemen Dan Inovasi, 8(3), 104-133. R

Nimas Lailia, Q., Suryoko, S., Saryadi. 2012. Pengaruh Kualitas Pelayanan, Harga dan Nilai Pelanggan Terhadap Kepuasan Pelanggan Pengguna Jasa Servis Bengkel AHASS 0002 Semarang Honda Center. Dipenogoro Journal of Social and Politic, 1-8.

Nursiana, A. 2018. Pengaruh Kualitas Layanan Terhadap Loyalitas Nasabah Dengan Intermediasi Kepuasan Nasabah Dan Nilai Yang Dirasakan Nasabah. ULTIMA Management, 3(1), 1-15.

Parasuraman, A., Zeithaml, V., Berry, L. 1988. SERVQUAL: A Multiple-Item Scale for Measuring Consumer Perceptions of Service Quality. Jorunal of Retailing, 64(1), 12-40.

Rahab., Handayani S.R., \& Nawarini A.T. 2015. Peran Perceived Value dan Kepuasan Pelanggan Dalam Upaya Membangun Loyalitas Pengguna Kartu Seluler. Media Ekonomi dan Manajemen. 30(1). hal.76-84.

Sawitri, N. P., Yasa, N. N. K., \& Jawas, A. 2013. Pengaruh Kualitas Pelayanan Terhadap Kepuasan Dan Loyalitas Pelanggan Tegal Sari Accommodation Di Ubud. Jurnal Manajemen, Strategi Bisnis, Dan Kewirausahaan, 7(1), 40-47.

Setiawan, H., Minarsih, M. M., \& Fathoni, A. 2016. Pengaruh Kualitas Produk, Kualitas Pelayanan Dan Kepercayaan Terhadap Kepuasan Nasabah Dan Loyalitas Nasabah Dengan Kepuasan Sebagai Variabel Intervening. Journal Of Management, 2(2), 1-17.

Siddiqi, K. O. 2014. Interrelations between Service Quality Attributes, Customer Satisfaction and Customer Loyalty in the Retail Banking Sector in Bangladesh. International Journal of Business and Management, 6(3), 1236.

Thakur, S., \& Singh, A. P. 2012. International Journal of Management Research and Review Impact of Service Quality on Customer Satisfaction and Loyalty: in the Context of Retail Outlets in Db City Shopping. International Journal of Management Research and Review, 2(2), 334-344.

Te Tu, Yu, Lien Li, Mei., and Chi Cih. Hen. 2013. An Empirical Study of Corporate Brand Image, Customer Perceived Value and Satisfaction on Loyalty in Shoe Industry. Journal of Economics and Behavioral Studies, 5(7), pp. 469- 483 
Utari, Woro. 2010. Kepuasan Pelanggan Sebagai Moderating Variabel Guna Meningkatkan Loyalitas Pelanggan pada Maskapai Penerbangan.Jurnal Mitra Ekonomi dan Manajemen Bisnis, 1 (2) pp 137-151

Wijaya, I Putu Surya Ananta \& I Nyoman Nurcaya. 2017. Kepuasan Pelanggan Memediasi Kualitas Produk Dan Kewajaran Harga Terhadap Loyalitas Merek Mcdonalds Di Kota Denpasar. E-Jurnal Manajemen Unud. 6(3). hal.15341563

Wong, Amy and Sohal, Amrik. 2003. Service quality and customer loyalty perspectives on two levels of retail relationship. The Journal of Services Marketing. 17 (5).pg. 495-511

Zarei, E., Daneshkohan, A., Pouragha, B., Marzban, S., Arab, M. 2014. An Empirical Study of the Impact of Service Quality on Patient Satisfaction in Private Hospitals, Iran. Global Journal of Health Science, 7(1), 71-77. 